\title{
Patient perspectives on the impact of acromegaly: results from individual and group interviews
}

This article was published in the following Dove Press journal:

Patient Preference and Adherence

9 January 2014

Number of times this article has been viewed

\section{Michelle H Gurel' \\ Paul R Bruening ${ }^{2}$ \\ Christine Rhodes ${ }^{2}$ \\ Kathleen G Lomax ${ }^{3}$}

'Neuroendocrine Clinical Center, Massachusetts General Hospital, Boston, MA, USA; ${ }^{2}$ Nicholas Research Associates International, New York, NY, USA; ${ }^{3}$ Medical Affairs, Ipsen Biopharmaceuticals, Inc., Basking Ridge, NJ, USA
Correspondence: Michelle H Gurel Neuroendocrine Clinical Center, Massachusetts General Hospital, Zero Emerson Place, Boston, MA 02I I4, USA Tel +l 6177240145

Fax + | 617726 |24|

Email mgurel@partners.org
Purpose: Acromegaly is a chronic condition resulting from a growth hormone-secreting pituitary tumor that can substantially impact patients' physical and emotional well-being. We sought to understand the impact of acromegaly on disease-related concerns and treatment choices from the patient perspective. The path to diagnosis, current disease management, interactions with the treating health care providers (HCPs), and support networks were also assessed.

Methods: Acromegaly patients were recruited primarily from a patient support group (Acromegaly Community). In Phase I, ten patients participated over the course of 5 days in a moderated online discussion board and they answered questions about their disease. In Phase II, a separate nine-patient cohort participated in face-to-face interviews conducted during an acromegaly patient conference. Data were summarized qualitatively by grouping similar answers and quotations.

Results: Nineteen acromegaly patients were recruited across the two cohorts, and both groups shared similar concerns. They demonstrated a notable interest in understanding their disease and its treatment. Patients were focused on the impact of the disease on their life, and they expressed a desire to get beyond reminders of their disease. The patients described long journeys to a correct diagnosis and relief at having a name for their condition. Many shared a sense of shock at needing pituitary surgery and felt unsatisfied by the treatment decision process, motivating them to discuss it with other patients. Patients not connected to a patient support group reported feeling helpless and lonely. Most patients shared a desire to improve their general knowledge about acromegaly to spare others their protracted diagnostic period. Patients also reported hesitancy in asking questions or sharing details about the disease's impact on their lives with their HCPs.

Conclusion: Acromegaly can be a life-changing diagnosis with profound, ongoing effects on patients' lives. Patients struggle with many issues they fail to openly share with their HCPs, but may discuss these issues more easily with other acromegaly patients. Better collaboration between patients and care providers could lead to increased patient satisfaction.

Keywords: acromegaly, impact on patients' lives, patient perspective, somatostatin analogs

\section{Introduction}

Acromegaly is a chronic condition most often resulting from a benign, growth hormone $(\mathrm{GH})$-secreting pituitary adenoma. ${ }^{1-3}$ It is a relatively rare disease, with an incidence of approximately 3 per million per year, and a prevalence of approximately 40-130 per million in Europe. ${ }^{4,5}$ Physical manifestations are varied and are based both on local effects of the tumor and on prolonged elevation of $\mathrm{GH}$ and insulin-like growth factor 1 (IGF-1) levels. For example, visual disturbances may arise from compression of the optic chiasm by the tumor, whereas features associated with excess GH 
include soft-tissue swelling, bone and joint disease (including osteoarthritis), sleep apnea, impaired glucose tolerance and diabetes, menstrual dysfunction, and respiratory and cardiovascular complications. ${ }^{1,2}$ Acromegaly is also associated with increased mortality rates, particularly among patients with cardiovascular comorbidities. ${ }^{6}$ Diagnostic clinical features such as acral overgrowth and jaw prognathism are slow to develop, and there may be a delay of many years between the onset of symptoms and diagnosis. ${ }^{7}$ Diagnosis is confirmed through the assessment of GH and IGF-1 levels, in combination with imaging of the pituitary to identify and characterize the adenoma. ${ }^{8}$

Primary treatment is generally surgical resection of the pituitary tumor, particularly for smaller tumors $(<1 \mathrm{~cm})$ and for larger tumors causing local compression effects. ${ }^{1,2}$ Transsphenoidal surgery, in which the pituitary is accessed via the nasal canal, is a common and quite well-tolerated first-line treatment for acromegaly, ${ }^{2}$ especially when performed by an expert pituitary surgeon. ${ }^{9}$ Complete resection may not be achieved, however, with a corresponding failure to normalize GH and IGF-1 levels. Pharmacologic therapy, including somatostatin analogs, GH receptor antagonists, and dopamine agonists (for example, cabergoline) are indicated for these patients, and also those for whom surgery is not appropriate. ${ }^{8}$ For patients not amenable to surgery, somatostatin analogs are considered first-line therapy. These include lanreotide and octreotide, which are both currently available in long-acting formulations (Somatuline ${ }^{\circledR}$ Depot; Ipsen Biopharmaceuticals, Inc., Basking Ridge, NJ, USA, ${ }^{10}$ and Sandostatin ${ }^{\circledR}$ LAR; Novartis Pharmaceuticals Corporation, East Hanover, NJ, USA, ${ }^{11}$ respectively) for injection every 4 weeks. Finally, radiotherapy is indicated for patients with inadequate biochemical control after undergoing surgery and/or receiving pharmacologic treatment. ${ }^{2}$

Acromegaly has been associated with substantial impairment in quality of life (QOL). Previous studies have attributed reduced QOL both to the disease, with its often considerable comorbidities, and to the burden of treatment. ${ }^{2,12-14}$ For example, the most severe functional impairment has been attributed to arthropathy, which may persist even in the presence of normalized GH and IGF-1 levels. ${ }^{1,2,15,16}$ General health, vitality, and physical appearance are other areas of particular concern to patients. ${ }^{12-14}$ Treatment carries a substantial burden. Surgery and radiotherapy are both associated with a risk of pituitary hormone insufficiency, while pharmacologic therapy may require substantial lifestyle adjustments and is associated with adverse events such as abdominal pain and diarrhea. ${ }^{2,10,11}$ Although treatment guidelines recommend addressing QOL concerns, ${ }^{8}$ the extent of dialogue between patients and health care providers (HCPs) concerning the impact of the disease on patients' lives is unclear.

This was a patient-focused qualitative study aimed at understanding the impact of acromegaly on patients' lives from their own perspectives. Key areas of inquiry included the path to diagnosis, the impact of diagnosis, and their attitudes toward treatment. We also sought to gain greater insight into the relationships between patients and HCPs, and among patients themselves. Specifically, we aimed to understand patients' primary concerns regarding the disease and the factors that increased their satisfaction with its management. One special feature of this study was the component of interactive discussions between patients, allowing perhaps a more in-depth exploration of issues of most interest to them, as well as the chance to capture patients' concerns in their own, often poignant, words.

\section{Methods}

\section{Data collection}

This qualitative research study was deployed in two phases comprised of moderated online discussions and in-person workshops. Both the online portion and the in-person workshops were moderated by Nicholas Research Associates International (New York, NY, USA). The online discussion board was conducted from May 21-25, 2012 and included ten patients. Multiple notices were placed to invite participation in the online discussion board; patients were recruited from an invitation placed on the patient support group, Acromegaly Community's website, ${ }^{17}$ (number $[\mathrm{n}]=9$ ); notices were also placed in endocrinologists' offices, on an acromegaly blogger's Facebook page (Facebook, Inc, Menlo Park, CA, USA), and via a recruiter with a medical database $(n=1)$. A moderator experienced in identifying patients with target conditions and skilled in facilitating online patient interactions contacted each participant in advance to conduct a screening interview, and to ascertain whether the opinions expressed were from actual acromegaly patients (for example, the participants were asked an open-ended question about what conditions they suffered from, and only people who mentioned acromegaly were included; also, participants were asked how and when they discovered they had acromegaly, what their first steps upon receiving the diagnosis were, and what treatments they had and were receiving). In-person workshops with nine patients were conducted from June 8-9, 2012, during the Acromegaly Community Conference in Las Vegas, Nevada, USA. For the in-person interviews, patients were either found at the conference itself and screened for their interest 
in participating $(n=5)$, or they were prescreened by phone $(n=7)$. Ultimately, three of the prescreened individuals were not able to participate due to sudden illness $(n=1)$, later discovery that they had multiple comorbidities that superseded their acromegaly treatment plan $(n=1)$, or lack of availability at the conference for an available time slot $(n=1)$.

The online discussion portion of the research was conducted over 5 days and focused on the patients' experiences living with acromegaly, including the path to diagnosis, acromegaly management (including treatment and medication choices), and interactions with HCPs. For the first 4 days, participants' comments were kept private from one another. On the fifth and final "wrap up" day, participants were permitted to see and react to the comments of the other participants in the discussion, allowing an element of interactivity to get more detailed responses to the questions.

In-person workshops were held during an Acromegaly Community Conference focused on patient support. Workshops were designed to gain insight into the patient/ HCP dialogue, including what questions patients are asking, what drives discussions about treatment, and what makes for the best patient/HCP interaction. Conversations focused on the styles of communication and relationships patients had developed with their HCPs, and the types of discussions they engaged in regarding treatment options.

\section{Data analysis}

Patient demographic data were summarized descriptively. Data from the online discussion board and in-person interviews were summarized qualitatively by categorizing similar responses.

\section{Ethical considerations}

All research participants were provided a statement on confidentiality and privacy before participating. The statement read: "All information you provide will be kept confidential; your participation is voluntary, and your name will not be used in any report or for marketing purposes". Online, the participants selected a box before participating; in-person, they were read the statement and asked for consent.

\section{Results \\ Patient demographics}

Patient demographics are presented in Table 1. A total of 19 patients participated in the study; ten in Phase I, and nine in Phase II, with the majority being female. The most common presenting symptoms were acral changes/change in height $(\mathrm{n}=10)$. Data regarding pharmacotherapy history
Table I Patient demographics and treatment history

\begin{tabular}{ll}
\hline Category & Results \\
\hline Age (years), mean $\pm \mathrm{SD}, \mathrm{N}=18$ & $4 \mathrm{I} \pm 9$ \\
Male/female, $\mathrm{N}=19$ & $7 / 12$ \\
Most common presenting symptoms, ${ }^{*} \mathrm{~N}=15$ & \\
Acral changes/change in height & 10 \\
Weight gain & 5 \\
Headaches & 5 \\
Diabetes mellitus & 4 \\
Breast discharge & 4 \\
Facial changes & 4 \\
Joint and/or muscle pain & 3 \\
Fatigue & 3 \\
Amenorrhea/irregular menstrual cycle & 3 \\
Current treatment, N=19 & \\
Somatostatin analogs & $12(63 \%)$ \\
GH receptor antagonist & $3(16 \%)$ \\
No medical therapy & $4(21 \%)$ \\
History of treatment since diagnosis, ${ }^{*} \mathrm{~N}=19$ & \\
One medication & $7(37 \%)$ \\
Two medications & $7(37 \%)$ \\
Three medications & $1(5 \%)$ \\
Four medications & $2(\mathrm{II} \%)$ \\
Surgery & $18(95 \%)$ \\
Radiation & $3(16 \%)$ \\
\hline
\end{tabular}

Note: *Multiple categories could be selected.

Abbreviations: SD, standard deviation; $\mathrm{N}$, number; $\mathrm{GH}$, growth hormone.

revealed that the majority of patients $(n=12)$ received a somatostatin analog at the time of the study. Several patients $(n=10)$ had a history of therapy with several different medications since the time of diagnosis. Eighteen patients had undergone surgery and three had received radiation.

\section{Patient profile}

Overall, the patients in both cohorts were characterized by a strong desire to become educated about their disease and to share their knowledge and experience with others. This outlook was driven by many factors, according to the interviews with patients, including the nature of acromegaly with its numerous and often painful symptoms, a sense of loss of identity and control over their lives, the long path to diagnosis, and the shock and concern regarding the treatment path that comes with a diagnosis of acromegaly (Table 2).

\section{Path to diagnosis}

Patients characterized the path to diagnosis as long and bewildering, with a great deal of suffering along the way. They described experiencing many different, often debilitating symptoms, sometimes over the course of years prior to diagnosis. These symptoms were frequently treated independently without recognizing that the patients were actually suffering from acromegaly, or they were dismissed by HCPs 
Table 2 Questions driving the need to know

\begin{tabular}{|c|c|}
\hline What is acromegaly? & $\begin{array}{l}\text {-Why am I experiencing all these symptoms? } \\
\text { - Why do I feel so bad? } \\
\text { - Why do I no longer look like myself? } \\
\text { - Why does no one seem to know what is } \\
\text { going on with me? }\end{array}$ \\
\hline $\begin{array}{l}\text { Will I ever feel like } \\
\text { myself again? As I did } \\
\text { before? }\end{array}$ & $\begin{array}{l}\text { - Will the treatments work? } \\
\text { - Can my GH and IGF-I levels get back to } \\
\text { normal? } \\
\text { - Will I be cured? Will my symptoms go away? } \\
\text { - Why do I have to be compliant? } \\
\text { - What happens if my levels start to rise? } \\
\text { What are my options? } \\
\text { - Have other hormones been affected? } \\
\text { energetic? Live a normal life? Have children? } \\
\text { Be able to work? Be able to forget, even for } \\
\text { a moment, that I have this disease? }\end{array}$ \\
\hline $\begin{array}{l}\text { What is treatment } \\
\text { like/what will I }\end{array}$ & $\begin{array}{l}\text { - Why brain surgery? What will happen? } \\
\text { How will I feel? }\end{array}$ \\
\hline experience? & $\begin{array}{l}\text { - What are the pros and cons of radiation? } \\
\text { Will it just cause more damage? Will I need } \\
\text { hormone replacement? Will it work? } \\
\text { - Why do I have to take these medications? } \\
\text { - How can I cope with the side effects? } \\
\text { have to have them so often? } \\
\text { - Aren't there easier solutions - like a once } \\
\text { daily pill? Something less intrusive? }\end{array}$ \\
\hline $\begin{array}{l}\text { How do I survive } \\
\text { financially? }\end{array}$ & $\begin{array}{l}\text { - Will my insurance cover me? What happens } \\
\text { if I lose my insurance? } \\
\text { - Can I afford the co-pays? } \\
\text { - What if I change insurers? }\end{array}$ \\
\hline
\end{tabular}

Abbreviations: $\mathrm{GH}$, growth hormone; IGF-I, insulin-like growth factor-I.

who did not quickly make the connection to the presence of a pituitary tumor or excess GH. Most of the patients saw multiple doctors prior to receiving the correct diagnosis, including internists (often more than one), gastroenterologists, gynecologists, orthopedists, neurosurgeons, and endocrinologists. They described incorrect and inadequate diagnoses (for example, sinus disorders or stress to explain the headaches, polycystic ovary syndrome to explain the menstrual problems) along the way. As one woman stated:

I visited ..... internists who were referred to me by my coworkers, and I heard everything from "you could be pregnant," "it's all in your head," "nothing is wrong with you," "you're obese," "you're just looking for pain medication."

I was given a pill for everything, and my bathroom looked like a pharmacy.

Conversely, patient denial can also be a factor in delayed diagnosis. Just as HCPs did not recognize the signs and symptoms of acromegaly, patients themselves ignored their symptoms until they got to the point where denial was impossible. A woman at the patient conference described:

Some time ... ago ... I started exhibiting signs ... most of which I completely ignored for three years ... I explained them away ... I don't have a large natural gifting of compassion ... okay ... everybody has something ... move on ... I was an extremely healthy person ... I never went to the doctor ... I never got sick ...... my rings got tighter, my feet got fatter and wider...I was gaining weight ... it's what happens after 35 , right? It was very easy to explain everything away ... my headaches gradually got worse ... I thought everybody has these kinds of headaches.

For this woman, the catalyst for her diagnosis was breast discharge. Her gynecologist listened, asked her detailed questions, and then suggested that she see an endocrinologist.

Although patients cited multiple triggers that finally led to diagnosis, the common feature was finding a doctor who recognized what the symptoms might mean, and either making the right referral or ordering the correct tests. Doctors who helped identify the diagnosis included a primary care physician, orthopedist, gynecologist, ophthalmologist, neurologist, dentist, and somnologist.

The long path to diagnosis shaped patients' attitudes towards the health care community and themselves. This often involved both a loss of trust in the medical profession and a loss of confidence in themselves, sometimes to the point where the patients felt as if they were crazy. In one patient's words:

Five years it took begging people to look at me ... so in a way how could I believe people's words ... the person who had to believe them was me ... this condition can drive someone mad, but it does not help with some of the medical profession's attitude.

\section{Impact of diagnosis}

From the patient perspective, the diagnosis seems to trigger both immediate relief combined with fear. There was relief at finally having confirmation that there was something wrong with them and that there was a name and a treatment for their condition. Immediate fear and anxiety arose from the knowledge that they may require pituitary surgery and may have to be on medication for the rest of their lives. A number spoke of putting on a brave front so as not to scare their family, friends, and coworkers, but of feeling very alone, frightened, and isolated on the inside because of the difficulties they faced. 
In some cases, there was residual anger toward the medical community because treatments or procedures that they went through along the way to diagnosis might not have been necessary if they had been diagnosed earlier. In addition, many patients mentioned their physical features would be less altered if they had been diagnosed earlier. Objections were also made about doctors emphasizing that the patients' tumors were "non-cancerous," perhaps in an attempt by the HCP to make the diagnosis of acromegaly seem less serious. Patients in interviews with each other did not react well to this minimization of the impact of their diagnosis because 1) transsphenoidal surgery to treat acromegaly is a serious procedure; 2) the surgery may not remove the entire tumor; 3) acromegaly affects many organs in the body; and 4) many patients have to be on medication - often multiple drugs - for the rest of their lives.

Diagnosis seemed to fuel a thirst for information among all the participants. They wanted to know in detail what was happening, what acromegaly is, and what is involved in its treatment (Table 2). Moreover, patients who suffered from not being diagnosed early appeared interested in sharing their stories, both for emotional release and for the greater good. Indeed, the idea of sparing others the long path to diagnosis was motivating to some participants as a way to turn their pain into something positive.

\section{Treatment goals from the patient perspective}

Patients' treatment goals focused more on their well-being and lessening the impact of acromegaly on their lives than on the long-term results of treatment, and this prioritization of short-term benefits may be at odds with their HCP's oftenunexpressed treatment goals. Overall, participants wished to feel as free from the disease as they could; for many, this meant feeling less symptomatic (no headaches, no joint pain, less fatigue, swelling of soft tissue reduced, and so on). Also of importance was getting their GH and IGF-1 levels under control. These were treatment goals they shared with their HCPs (Table 3), and controlling these hormone levels would mean fewer reminders of the disease in their daily lives. Patients mentioned repeatedly that their long-term goal was to feel that, in the words on one patient, "This is a disease that I have; it doesn't have me.”

\section{Taking back control/interacting with other patients (patient empowerment)}

Participants recognized that they had a disease for which the word "cure" does not often apply, particularly if they had to
Table 3 Treatment goals shared with health care professionals

\begin{tabular}{|c|c|}
\hline Medical treatment goals & How are they achieved? \\
\hline $\begin{array}{l}\text { - Reducing GH and IGF-I } \\
\text { levels to normal - or as } \\
\text { close to normal as possible }\end{array}$ & $\begin{array}{l}\text { - Transsphenoidal surgery } \\
\text { - Medication (if required) } \\
\text { - Radiation (if required) - most } \\
\text { push back against the idea of } \\
\text { radiation because of worry about } \\
\text { further damage to the pituitary } \\
\text { gland, which could necessitate } \\
\text { being on hormone replacement } \\
\text { for rest of one's life }\end{array}$ \\
\hline $\begin{array}{l}\text { Dealing with any comorbidities } \\
\text { that have arisen - high blood } \\
\text { pressure, diabetes, weight } \\
\text { gain, arthritis, poor vision, } \\
\text { pain, sleep apnea, heart } \\
\text { condition, jaw/teeth } \\
\text { problems, headaches }\end{array}$ & $\begin{array}{l}\text { Regular blood tests to monitor } \\
\text { levels and make certain } \\
\text { medications are working } \\
\text { - Hope/belief that symptoms will } \\
\text { disappear or at least be tolerable } \\
\text { if they consistently follow the } \\
\text { treatment guidelines and protocols }\end{array}$ \\
\hline
\end{tabular}

Abbreviations: GH, growth hormone; IGF-I, insulin-like growth factor-I.

face being on medication for the rest of their life. Treatment brought its own set of questions and stresses (Table 2) and presented a point of tension between being a patient and being a person. Participants expressed that their concerns go beyond being "biochemically normal." To this end, they make the treatment fit their real-life schedules. For example, some patients reported taking "drug holidays" just to feel free from the disease and its treatment (drug holidays they may not report to their HCPs). Other patients on injectable medications time the injection around work or travel schedules by receiving the injection over a weekend ("I can't do my job with diarrhea") or taking the shot prior to a big event ("I wanted to feel my best for the conference so I took my shot 5 days earlier to avoid having any breakthroughs here").

All the participants were characterized in one way or another by the degree to which they had educated themselves about the disease, at first through online sources and their own experiences, then additionally through listening to and sharing with each other. A driving desire for patients in both cohorts was to become knowledgeable because "knowledge is power", especially when patients felt as if they had lost control. They felt that doctors and other HCPs may know a lot, but they did too, as people with intimate, day-to-day knowledge of what living with acromegaly is like. For example, a few patients spoke about knowing that their symptoms were returning, or that something was happening in their bodies, before the "numbers" showed any change.

Participants emphasized the importance of the patientto-patient interaction (Table 4). They had quite often sought out a community with which to share their story and to find others with similar experiences. The few patients involved in 
Table 4 Lessons in patient empowerment

\begin{tabular}{|c|c|}
\hline Themes & Patient quotes \\
\hline $\begin{array}{l}\text { - Acromegaly is a disease or condition in which you are } \\
\text { the best judge of what is going on in your body } \\
\text { - You can recognize the signs and symptoms before anyone } \\
\text { else can, including if your current treatment is not working } \\
\text { for whatever reason } \\
\text { - You need to find doctors - endocrinologists, PCPs, } \\
\text { neurosurgeons - and all the specialists you might need to } \\
\text { help manage your different symptoms/comorbidities - who } \\
\text { will partner with you and treat you as a person first and a } \\
\text { patient second } \\
\text { - You need to find HCPs who know more than you (if at all } \\
\text { possible) - or at least are willing to learn and share their } \\
\text { learning and to accept you sharing your learning and } \\
\text { intimate knowledge of your body } \\
\text { - You need to be an advocate for yourself to be proactive } \\
\text { in your own care } \\
\text { - You need to recognize your own need for help and } \\
\text { support-you cannot do this alone } \\
\text { - You need to learn to accept what has happened, which } \\
\text { makes this as much an emotional, psychological, and } \\
\text { spiritual journey as a physical journey }\end{array}$ & $\begin{array}{l}\text { - "I know my body better than anyone else and I know when it is bad and } \\
\text { when it is good ... I know so many people with acromegaly that listen to } \\
\text { their doctors like they are gods and many of them have no pituitary function } \\
\text { but still have acromegaly" } \\
\text { - "I have been through a lot physically and emotionally. Acromegaly has taken } \\
\text { over and changed my life completely. It has altered my path ... thank } \\
\text { goodness I found the Acromegaly Community over the Internet. They have } \\
\text { been the only true support I get. They are the only ones that understand } \\
\text { what I am going through. The fact that I can discuss the strange symptoms } \\
\text { and compare notes with others makes a big difference. If you talk about all } \\
\text { of this to a friend or family member, it's not the same. The doctor doesn't } \\
\text { get it either" } \\
\text { - "I own the car and I'm driving it ... the first doctor I saw was more flash } \\
\text { and glam ... so I got a new endo ... she's only had } 3 \text { acro patients ... the } \\
\text { first endo had so many, but was too busy for me ... I am very convincing ... } \\
\text { I just feel it's my body..." } \\
\text { "Since becoming ill, I've lost my career, my home, my savings, my husband, } \\
\text { my self-worth, and most of all my love for life. I live every day in constant } \\
\text { pain and suffer from pounding migraines, back pain, arthritis, nerve pain } \\
\text { from fibromyalgia and am never pain-free ... for a long time, I was really, } \\
\text { really mad about having acromegaly, but now have realized it's my purpose. } \\
\text { It has made me a stronger, wiser, and kinder person ... I am one of the } \\
\text { faces and voices for acromegaly and have always offered kindness, love, } \\
\text { knowledge, experience and support to anyone who is in need ... remember, } \\
\text { be kinder than necessary, because everyone is fighting some kind of battle" }\end{array}$ \\
\hline
\end{tabular}

Abbreviations: HCPs, health care providers; PCPs, primary care physicians; endo, endocrinologist; acro, acromegaly.

the cohorts who had not actively participated in group-sharing with other acromegaly patients described feeling alone and helpless. In the interviews (both online and in-person), respondents repeatedly emphasized not only how much support they get from each other, but how much they learn, including the following: 1) hearing each other's stories; 2) encouraging each other to take control and learn to trust their own bodies; and 3) seeking to become patient advocates - first and foremost for their own care, but also for other acromegaly patients through sharing their knowledge of what works for them (Table 5). An underlying assumption seems to be that only other patients with acromegaly truly know what it is like to have the disease and what it is like to have to deal with its treatment regimens.

Patients recognized the value of themselves and their experience as educators and advocates. The patient research suggested that a number of patients are also ready and willing to share their experiences with the medical community. There was a strong belief among some patients - particularly those diagnosed later in life - that one of the ways they can make a difference and put their experience to good use was to ensure that acromegaly is diagnosed earlier in others. They expressed a desire to raise the profile of acromegaly as a disease that, though rare, should be better recognized by HCPs (particularly primary care providers) when dealing with presenting symptoms. Patients' recommendations of the best resources for other patients are summarized in Table 5.

\section{Interaction with HCPs}

Endocrinologists are clearly on the front lines in making the diagnosis and in managing treatment, but it was also clear in the patient interviews that some endocrinologists were more effective than others. One of the greatest divides in this research was between patients who had found doctors who listened to them, took a more collaborative approach, and were willing to work with them, and patients who had not found such HCPs. Having doctors who do not really listen to them was one of the main factors that seemed to drive patients online.

The quality of the relationship with the doctor appeared to be critical to patient trust and confidence, and a great range of partnership experiences was reported (Figure 1). Some components contributing to successful and poor partnerships are illustrated in Figure 1. Without compassion, empathy, and a solid base of information, the "orphan" nature of the disease can end up making the patients themselves feel like orphans whom nobody in the medical community wants. Patient recommendations to the health care community are summarized in Table 6. 
Table 5 Best patient resources

\begin{tabular}{|c|c|}
\hline Best resource & Why? \\
\hline $\begin{array}{l}\text { An endocrinologist who cares, is knowledgeable, informed, } \\
\text { up to date, proactive, and positive }\end{array}$ & $\begin{array}{l}\text { - All of which "can make this a very manageable disease" } \\
\text { - "My most important resource is my endocrinologist ... He has helped me through } \\
\text { some very difficult times" } \\
\text { - "I would say that my local endo is my best resource for my management. We } \\
\text { have a very open dialogue and I can email him at any time. He keeps up with the } \\
\text { newest guidelines and does his best to help me" }\end{array}$ \\
\hline Acromegaly specialist or team & $\begin{array}{l}\text { - Only one or two seemed to be in this position, but best practice as a patient is } \\
\text { still to "follow up with your neuro/endo, radiation/oncologist, make sure your } \\
\text { primary doctor is aware of everything you're being treated for ... and do your } \\
\text { own research" }\end{array}$ \\
\hline Internet - but can be a double-edged sword & $\begin{array}{l}\text { - Positive - in the context of a good relationship with an endocrinologist, but not } \\
\text { as a substitute for it - "I wouldn't know nearly what I know today without the } \\
\text { Internet. I was able to get actual medical articles to show my Dr... That took so } \\
\text { much weight off my shoulders" } \\
\text { - Problematic - if you don't have an endocrinologist you can trust, then "you don't } \\
\text { know who you can believe;" and "all sites say the same things" }\end{array}$ \\
\hline Patient sites like acromegalycommunity.com & $\begin{array}{l}\text { - "It's been a godsend ... it is such a rare condition and hardly anyone understands } \\
\text { unless they have it ... I am looking to going to Vegas and see my acro family again" } \\
\text { - "It's been so great to talk with other people who know how I am feeling" } \\
\text { - "My online support group is by far the most important resource right now. } \\
\text { Listening to what other patients are being told by their specialists is how I am } \\
\text { learning more" }\end{array}$ \\
\hline
\end{tabular}

Abbreviations: acro, acromegaly; endo, endocrinologist; neuro, neurosurgeon.

Conference participants also made it clear that the more flexible or experienced the HCPs or treatment teams were, the greater the likelihood the patients would be willing to discuss their concerns and treatment preferences. Respondents who felt well taken care of by their HCPs described two-way conversations with them about treatment options. Conversely, patients who thought their providers were not knowledgeable about the disease ("because it is so rare") felt a strong resistance from their $\mathrm{HCP}$ to changing their medicine (despite patient inquiry). More often, the less satisfied patients felt they were "the only acromegaly patient this doctor has", or they were concerned that their HCP "was not aware of what is out there." Patients in this category were less willing to discuss the impact of acromegaly on their lives. As one patient stated:

I have a long list in my hand ready to ask, but something inside me every time tells me, just be quiet; the doctor is not going to have anything new to say, and she is going to tell you

\begin{tabular}{|c|c|c|c|}
\hline No partnership & Some partnership & Better partnership & True partnership \\
\hline $\begin{array}{l}\text { No/very little discussion with } \\
\text { doctor - little sense of doctor } \\
\text { being interested - may only } \\
\text { see the nurse - no real } \\
\text { conversations } \\
\text { No real chance to ask } \\
\text { questions, talk about } \\
\text { symptoms, or treatment } \\
\text { No treatment options ever } \\
\text { discussed or presented } \\
\text { Feeling trapped - no option to } \\
\text { move because of insurance } \\
\text { issues - can't go out of } \\
\text { network, on Medicaid }\end{array}$ & $\begin{array}{l}\text { Some reassurance getting } \\
\text { good/the best treatment - but } \\
\text { no real dialogue reported } \\
\text { Not clear about treatment } \\
\text { path - and not sure what } \\
\text { questions to ask } \\
\text { Some feeling of being left in } \\
\text { limbo with wait-and-see } \\
\text { approach } \\
\text { Do not/never understood why } \\
\text { need to wait for medical } \\
\text { therapy to start after operation } \\
\text { Not clear what the medical } \\
\text { options are after surgery } \\
\text { Fear of going to the highest } \\
\text { dose on current drug because } \\
\text { what if they max out and there } \\
\text { is nowhere else to go? }\end{array}$ & $\begin{array}{l}\text { Clear presentation of the } \\
\text { treatment path and options } \\
\text { along the way } \\
\text { Feel listened to and } \\
\text { understood - had questions } \\
\text { answered } \\
\text { Different treatments fully } \\
\text { explained and presented as } \\
\text { options - impression of HCP } \\
\text { as thinking and crafting a } \\
\text { treatment approach that meets } \\
\text { their individual needs } \\
\text { Regularly monitored and any } \\
\text { changes in treatment explained } \\
\text { in terms of the medical goals } \\
\text { and their goals as patient } \\
\text { (return to as normal functioning } \\
\text { as possible) } \\
\text { Know that multi-drug cocktails } \\
\text { possible }\end{array}$ & $\begin{array}{l}\text { Recognition by endocrinologist } \\
\text { that patient is knowledgeable and } \\
\text { can be a partner in their } \\
\text { care - endocrinologist willing } \\
\text { to listen and learn in concert with } \\
\text { patient (important for patients not } \\
\text { near centers of excelence) - real } \\
\text { sharing or information and } \\
\text { knowledge between } \\
\text { endocrinologist and patient - } \\
\text { each learning as they go } \\
\text { Endocrinologist willing to try } \\
\text { things that are not "on the books;" } \\
\text { eg, shorten length of time } \\
\text { between shots } \\
\text { Patient challenge to accepted } \\
\text { procedures; eg, refusing gamma } \\
\text { knife treatment and insisting on } \\
\text { breast tumor removal instead; } \\
\text { insisting on continuing treatment } \\
\text { while trying to conceive and } \\
\text { convincing doctor because of } \\
\text { research presented by patient }\end{array}$ \\
\hline
\end{tabular}

Figure I Patient/HCP partnership.

Abbreviation: $\mathrm{HCP}$, health care provider. 
Table 6 Patient suggestions to the health care community

Serving patients better
More/better education of HCPs on acromegaly

Earlier diagnosis

Greater compassion, empathy, and understanding on the part of HCPs

Involve PCPs in care plan

Offer counseling for emotional and psychological issues

Inform newly diagnosed patients about the acromegaly community (acromegalycommunity.com)

\section{Why? How?}

- Recognize that patients are a resource and can help - (HCPs) "need to be much better educated about acromegaly, not just by the textbooks, but by people with acromegaly"

- Scheduled events with nurses and doctors where patients speak as well - "a lot of them (nurses, doctors, medical students) have never seen an acro patient up close and my face tells it all"

- A public education/awareness campaign - "ideally, we should also strive to educate the public so they can ask the right questions of their doctors"

- Better education of PCPs seen as critical - "Ever since I discovered acromegaly the question that haunted me was why did it take so long to recognize it given the fact that once you know what you are looking at, the information is all over the place. For me it is about educating those who should be in a position to recognize the condition early so more people can be cured and not just treated"

- "I think that doctors and nurses could benefit from reading the posts by the people that are in the support group on Facebook. By hearing what people are going through, they may have more compassion for their patients .... Many of us feel like every day that goes by with acromegaly, we are changing into monsters. That we are losing our identities. Those of us on Facebook feel like we look like each other, as if we are all blood related. It can be a hard thing to accept that we no longer look like our family but like strangers we see on the internet. Our doctors and nurses need more empathy"

- "Take your time and explain everything to me good or bad thoroughly ... assure me that in time we will do our best to manage your acromegaly ... always continue to be concerned and always empower yourselves of the different treatments that are available and let your patients know"

- Greater contact between endocrinologists and PCPs - "the endo should not work alone"

- "I think a lot of people with acromegaly experience depression and don't know how to handle it"

- "Most patients will not speak up or may underestimate how they feel ... don't wait for the patient to express concern"

- "So they don't walk out not knowing where to go after the news just got dropped on them that they have acro"

Abbreviations: HCPs, health care providers; acro, acromegaly; PCPs, primary care physicians; endo, endocrinologist.

that we will wait and see how you are the next visit. I tuck my paper back in my pocket and just ask for a few little things. I never get answers for any questions I ask. They never have answers, and my acro is more rare than others, which greatly reduces the chances of getting any help I need. Nobody knows what to do for me but to sit back and watch me get sicker ... watch me what? Watch me die? Watch me suffer? Watch me as I slip back into a deep depression? Dealing with this disease is always a waiting game, a mind-twisting, emotioncrushing game that never ends.

\section{Discussion}

Relatively little is known about patient perspectives on the process leading to a diagnosis of acromegaly. One recent study in acromegaly patients established a correlation between psychosocial impairment and diagnostic delay. ${ }^{18}$ The present research demonstrates that the path to diagnosis can be a long and frustrating process, with substantial physical and emotional suffering along the way. Patient perceptions regarding the health care community appear to be strongly influenced by their experiences during this diagnostic process. These perceptions may influence attitudes toward subsequent treatment, including the extent to which patients discuss lifestyle issues with their HCPs. Indeed, the quality of the patient/HCP interaction appeared to be directly associated with the degree of partnership that patients felt in the relationship. Patients with a good partnership with their HCP were more willing to discuss the disease's impact on their lives with them.

For most respondents, establishing a good HCP partnership had proven difficult. Even relationships with family members and other caregivers did not appear to offer the same level of understanding that they reached through interaction with other patients with acromegaly. These patients were 
motivated to reach out to one another for support, education, and advice. They were also motivated to assist in educating the health care community about acromegaly and its effects on their lives.

How can the patient experience along the path to diagnosis and subsequent treatment be improved? From this research, finding an endocrinologist or other HCP who is knowledgeable, caring, and open to collaborative discussions and decision making was a key recommendation for patients. Also important was becoming connected to a patient community. These ideas were reflected in patients' recommendations to the health care community: they urged providers to become better educated about acromegaly; to work collaboratively with other HCPs and with patients; and to assist patients in accessing resources outside of the medical setting.

It is important to note that this was a qualitative study drawn from discussions with 19 acromegaly patients. Most of the patients were already active in an acromegaly support group, so the opinions they expressed could be biased toward a more activist patient interested in sharing of information between patients, and many were committed enough to attend a disease-specific patient conference. Other sources of bias in this small interactive patient study include the fact that most of the participants failed to achieve surgical remission, were on pharmacological therapy, and lived in the United States.

\section{Conclusion}

From diagnosis through treatment, acromegaly is associated with profound physical and emotional consequences. Patients struggle with many issues they fail to openly share with their HCPs. Those with acromegaly suffer from not being diagnosed early and, as a result, appear interested in sharing their story for personal release and the greater good, as evidenced by the many moving quotes captured during this study's interactive patient interviews. Their interactions with HCPs are shaped by the long path to diagnosis and by what is perceived as a general lack of information about the disease in the health care community. Further studies that investigated patient concerns and perspectives on acromegaly and its treatment could lead to better collaboration between patients and providers, and could result in increased patient satisfaction.

\section{Acknowledgments}

The Acromegaly Community Conference was organized by Wayne Brown. Paul Bruening moderated the online bulletin board discussions and the in-person workshops.
Eric Bertelsen, $\mathrm{PhD}$, from Arbor Communications, Inc, and Rosemarie Kelly, PhD, Ipsen consultant, provided writing assistance. The authors would like to thank all of the patients who participated in this study. The research was funded by Ipsen Biopharmaceuticals, Inc.

\section{Disclosure}

Michelle Gurel is a nurse consultant to Ipsen Bipharmaceuticals, Inc., and Kathleen Lomax, MD, is an employee of Ipsen Bipharmaceuticals, Inc. Paul Bruening and Christine Rhodes were contracted by Ipsen Biopharmaceuticals, Inc., to perform and report on the research described here. The authors report no other conflicts of interest in this work.

\section{References}

1. Melmed S. Medical progress: acromegaly. $N$ Engl J Med. 2006; 355(24):2558-2573.

2. Adelman DT, Liebert KJ, Nachtigall LB, Lamerson M, Bakker B. Acromegaly: the disease, its impact on patients, and managing the burden of long-term treatment. Int J Gen Med. 2013;6:31-38.

3. Sanno N, Teramoto A, Osamura RY, et al. Pathology of pituitary tumors. Neurosurg Clin NAm. 2003;14(1):25-39, vi.

4. Holdaway IM, Rajasoorya C. Epidemiology of acromegaly. Pituitary. 1999;2(1):29-41.

5. Chanson P, Salenave S, Kamenicky P, Cazabat L, Young J. Pituitary tumours: acromegaly. Best Pract Res Clin Endocrinol Metab. 2009; 23(5):555-574.

6. Sherlock M, Ayuk J, Tomlinson JW, et al. Mortality in patients with pituitary disease. Endocr Rev. 2010;31(3):301-342.

7. Rajasoorya C, Holdaway IM, Wrightson P, Scott DJ, Ibbertson HK. Determinants of clinical outcome and survival in acromegaly. Clin Endocrinol (Oxf). 1994;41(1):95-102.

8. Katznelson L, Atkinson JL, Cook DM, Ezzat SZ, Hamrahian AH, Miller KK; American Association of Clinical Endocrinologists. American Association of Clinical Endocrinologists medical guidelines for clinical practice for the diagnosis and treatment of acromegaly 2011 update. Endocr Pract. 2011;17 Suppl 4:1-44.

9. Barker FG, Klibanski A, Swearingen B. Transsphenoidal surgery for pituitary tumors in the United States, 1996-2000: mortality, morbidity, and the effects of hospital and surgeon volume. J Clin Endocrinol Metab. 2003;88(10):4709-4719.

10. Somatuline ${ }^{\circledR}$ Depot (lanreotide) [prescribing Information]. Basking Ridge, NJ: Ipsen Biopharmaceuticals, Inc.; 2013.

11. Sandostatin ${ }^{\circledR}$ LAR Depot (octreotide acetate) [prescribing information]. East Hanover, NJ: Novartis Pharmaceuticals Corporation; 2011.

12. Rowles SV, Prieto L, Badia X, Shalet SM, Webb SM, Trainer PJ. Quality of life (QOL) in patients with acromegaly is severely impaired: use of a novel measure of QOL: acromegaly quality of life questionnaire. J Clin Endocrinol Metab. 2005;90(6):3337-3341.

13. Webb SM, Badia X, Surinach NL; Spanish AcroQoL Study Group. Validity and clinical applicability of the acromegaly quality of life questionnaire, AcroQoL: a 6-month prospective study. Eur J Endocrinol. 2006;155(2):269-277.

14. T'Sjoen G, Bex M, Maiter D, Velkeniers B, Abs R. Health-related quality of life in acromegalic subjects: data from AcroBel, the Belgian registry on acromegaly. Eur J Endocrinol. 2007;157(4): 411-417.

15. Biermasz NR, Pereira AM, Smit JW, Romijn JA, Roelfsema F. Morbidity after long-term remission for acromegaly: persisting joint-related complaints cause reduced quality of life. J Clin Endocrinol Metab. 2005;90(5):2731-2739. 
16. Wassenaar MJ, Biermasz NR, Kloppenburg M, et al. Clinical osteoarthritis predicts physical and psychological QoL in acromegaly patients. Growth Horm IGF Res. 2010;20(3):226-233.

17. Acromegaly community [homepage on the Internet]. Available from: http://www.acromegalycommunity.com. Accessed December 24, 2013.
18. Siegel S, Streetz-van der Werf C, Schott JS, Nolte K, Karges W, Kreitschmann-Andermahr I. Diagnostic delay is associated with psychosocial impairment in acromegaly. Pituitary. 2013;16(4):507-514.

\section{Publish your work in this journal}

Patient Preference and Adherence is an international, peer-reviewed, open access journal focusing on the growing importance of patient preference and adherence throughout the therapeutic continuum. Patient satisfaction, acceptability, quality of life, compliance, persistence and their role in developing new therapeutic modalities and compounds to optimize clinical outcomes for existing disease states are major areas of interest. This journal has been accepted for indexing on PubMed Central. The manuscript management system is completely online and includes a very quick and fair peer-review system. Visit http://www.dovepress.com/ testimonials.php to read real quotes from published authors.

Submit your manuscript here: http://www.dovepress.com/patient-preference-and-adherence-journal 